\title{
The Impacts of Regional Governments' Expenditures on the Agricultural Sector and Economic Performance in Indonesia
}

\author{
Budiyanto, D.S. Priyarsono, Bonar M. Sinaga, Tahlim Sudaryanto \\ Bogor Agricultural University, Indonesia/Haluoleo University, Indonesia \\ Bogor Agricultural University, Indonesia \\ Bogor Agricultural University, Indonesia \\ Ministry of Agriculture, Indonesia
}

\begin{abstract}
The amount and composition of government expenditure in fiscal operations has a significant impact on aggregate demand and national output and affects resource allocationin an economy. Therefore, in order to achieve effective economic development, regional government spending has to be allocated appropriately according to the potentials of each area. The purpose of the study is to examine the impacts of regional government spending on investment, employment, economic growth, and poverty in the areas where the contribution of the agricultural sector to GRDP is high and low. This Study utilizes an econometric model of simultaneous equations system using panel data of 20 provinces in Indonesia for the period of 2003-2011. Several simulations (counter-factual experiments) were conducted. The 20 sampled provinces were classified into two groups based on the contribution of agricultural sector to the respective regional economy. In provinces where the agricultural sector is dominant, an increase in government spending on agriculture-subject to a constant total government expenditure--increases the total investment, total employment, the total $G R D P$, and decreases poverty rate. On the other hand, in provinces where agriculture is not dominant, it decreases the total investment.
\end{abstract}

Keywords: government expenditure, investment, employment, GRDP, poverty.

\section{Introduction}

Government spending plays a vital role in achieving the goals of economic development of a country (Jhingan, 2008). Therefore, the amount and composition of government expenditure should be well established. On the other hand, although the development has to cover all economic sectors, considering the limitations of resources, it is necessary to set priorities for a particular sector.

According to Kaldor's hypothesis, manufacturing is the engine of economic growth in a region, while Mellor (1995) states that empirically a country adopting development policies focusing on the agricultural sector has a tendency to be more successful in encouraging economic growth compared to that which emphasizes the development of non-agricultural sectors. Rostow (1960) states that the agricultural sector is a prerequisite for the development of reliable industrial and service sectors.Should the development policy in Indonesia today emphasize the agricultural sector or non-agricultural sectors?

Since 2012, in terms of public administration,Indonesia has consisted of 33 provinces with 497 regencies/cities, all of which have different potentials in natural as well as human resources. The agricultural sector in most areas still plays a very important role in their economies, but in some others, agriculture is less dominant. Should the regions or provinces whose contribution in the agricultural sector to Gross Regional Domestic Product (GRDP) is relatively high need to increase or decrease the proportion of public spending (government spending) on the agricultural sector to be more effective in achieving their goals of economic development? Similarly, should the areas whose agricultural sector contribution to GRDP is relatively low do the same? In this regard, this study seeks to examine the impacts of government spending on investment, employment and unemployment, economic growth, and poverty in the areas where the contributionof the agricultural sector to GRDP is either high or low.

\section{Literature Reviews}

\section{Correlation between Government Spending and Agricultural Sector Performance}

In theory, the amount of regional expenditure is not determined by regional revenue; on the contrary, regional revenue is influenced by the needs of the region. When a fiscal need increases, the regional government will strive to improve its revenue (Stiglitz, 2000; Musgrave and Peggy, 1989).

Based on the result of FAO's research project in 20 countries of Latin America, there is an evidence which shows that the volume and composition of public expenditure in rural areas has a positive impact on agricultural growth.The study also shows that the assumption of a certain amount of government expenditure on the agricultural sector, where the expenditure share of private input subsidies is high and the provision of public 
goods is low, will have a negative impact on agricultural growth (World Bank, 2009). Lopez and Galinato (2007) find similar results that the positive impact of public spending on rural incomes is highly dependent on the composition of public spending. They estimate that the reallocation of subsidized private properties to provide public goods by 10 percent increases the per capita income of the agricultural sector by 5 percent. In Indonesia, Fugli (2004) identified the determinants of the agricultural growth from 1960 to 2000 and found that from the 1970 s to 1980 productivity increased, but since the early 1990 s it has tended to level off. Most of the growth in the agricultural sector is determined by the increased use of input.

\section{Correlation between Government Spending and Private Investment}

Opinions differ concerning the impact of an increase in government spending on investment. The traditional one states that an increase in government spending causes a crowding-out of private investment. The non-traditional one argues that government spending may stimulate investment (Ahmed and Miller, 2000). Barro (1990) found that high income taxes (taxes used for government spending) caused a reduction in after-tax profits of private investment, resulting in decreased investment, and ultimately it had a negative impact on economic growth. He also found that government spending from the taxes could be allocated to finance unproductive (consumption) services and productive services. Unlike government expenditure on consumption, government spending on productive services has a positive effect on growth. If the growth is the result of the accumulation of private capital, it can exceed the negative effect of high taxes on growth.

If government spending-primarily funded by the loan-increases, the interest rate on the money market will go up due to the increased demand for money. Consequently, private investment will be reduced. Another opinion says that an increase in government spending will lead to further increase in the level of income that can in turn increase private investment, due to an increase in savings as a result of the increase in revenue, which also encourage greater investment. In addition, still another opinion says that the increase in government spending will not cause investment to fall if the private agents give discount interest rates on government loans by comparing or considering the expectationof tax rise when they conduct investment, making the government's fiscal policy irrelevant to private investment and output level (Wang, 2005).

According to neoclassical argument, the main focus should be on the subtitusional or complementary correlation between government spending and private investment. A subtitusional hypothesis is derived from the notion that increased government spending on capital goods will increase capital accumulation which exceeds the optimum level, so that investors will reduce their investments in order to maintain the optimum level of capital accumulation in the economy. Thereby, government expenditure on capital goods will crowd out private investment. In contrast, a complementary hypothesis states that government spending on infrastructure and human capital can increase the marginal productivity of private capital, and therefore induce more private investment.

\section{Correlation between Government Spending and Labor Absorption}

Labor demand curve shows the inclination of the descending line on labor wages. This is in line with a company production process, where the company will use the optimal amount of labor to achieve corporate objectives, namely gaining a maximum profit. The optimal number of labor utilization is achieved when the value of the marginal physical product of labor is equal to the labor wages which are the marginal cost for one unit of labor. Therefore, the company will adjust the amount of labor used in accordance with the cost (wages) of the labor. If wages increase, the company will reduce the amount of labor used (Branson, 1979).

Theorically, the increased economic growth will increase employment by assuming an increase in investment. However, Indonesia's effort to reduce the amount of open unemployment through the increased economic growth has not brought a significant result. This is because economic growth in recent years tends to be driven by increased consumption, while investment does not increase but decreased. Thus, even though the economy has improved, job creation is very slow (Priyarsono, 2011).

\section{Correlation between Government Expenditure and Economic Growth}

In terms of aggregate supply, regional economic growth is based on the approach to aggregate production function which is the function of technology, capital (physical and financial capital) and labor. Based on the theory of endogenous growth (Todaro, 2000), output growth is affected by technology, capital and human capital that are integrated with science.

Actually, there is still a debate on public spending (government spending) in relation with economic growth--whether public expenditure determines economic growth or economic development results in the expansion of government spending. Famous economists Wagner dan Keynes have different opinions on this issue. Adolf Wagner, well-known for his Wagner's Law, is probably the first scholar to recognize a positive correlation between economic growth and the growth of government activities. One of the interpretations of the law is an increase in economic activity will lead to an increase in the activity of the government, as a result of an 
increase in public expenditure. Implicitly, it can be concluded that public expenditure can be treated as an outcome or endogenous factor of economic growth. Keynes considers public spending as exogenous factor that can be used as a policy instrument to stimulate economic growth (Liu, Hsu, and Younis, 2008).

\section{Correlation between Government Spending and Poverty}

Priyarsono (2011) concluded that economic growth effectively reduced poverty in the province of Riau, but at the same time the increased economic growth created a wider income disparity. Meanwhile, Bourguinon (2004) stated that poverty could be reduced not only by economic growth but also by improving income distribution.

The growth in the agricultural sector has been proven to have the ability to reduce poverty in all types of countries. Cross-country estimates indicate that Gross Domestic Product (GDP) growth is fueled by agriculture at least twice more effective in reducing poverty than the GDP growth caused by non-agricultural sectors (World Bank, 2008).

Data

\section{Methodology}

This study uses panel data that includefiscal aspects, investment, employment, GRDP, and poverty data in 20 provinces in Indonesia from 2003 to 2011. Sources of the data are Central Bureau of Statistics, Directorate General of Fiscal Balance, Ministry of Finance, and Investment Coordinating Board. The fiscal data is the data accumulation of the realization of fiscal expenditure and government revenue of regencies, cities and provinces. Classification of regional government spending is based on Regulation of the Minister of Internal Affairs of the Republic of Indonesia Number 13 of 2006 on Regional Management Guidelines. The data collected from each province are grouped into two, namely provincial data that have the proportion of GRDP of high and low in the agricultural sector.

\section{Data analysis}

To solve the problem, the study uses an econometric model approach to the system of simultaneous equations. Agricultural Sector and economic performance is analyzed by estimation and simulation to predict the impact of an increase in government spending on agricultural and industrial sectors with a reduction in government spending on other sectors. The model is estimated with the method of Two Stage Least Squares (2SLS). Historical simulations are performed in the period 2003-2011.

Model

The model specified to perform the simulation consists of 15 structural equations and 5 identity equations.

Structural equations:

(1) $\quad$ INVSA $_{i t}=j_{0}+j_{1} P_{L S A}{ }_{i t}+j_{2} P P L+j_{3} T_{S B R}{ }_{i t}+j_{4} L W_{i t}+j_{5} P_{\text {POP }}{ }_{i t}+j_{6} L_{I N V S A} A_{i t}+j_{7} D_{i t}+u_{i t}$

(2) INVSNA $_{i t}=k_{0}+k_{1}$ PLSLL $_{i t}+k_{2}$ TSBR $_{i t}+k_{3}$ POP $_{i t}+k_{4} L_{\text {it }}+k_{5}$ LINVSNA $_{i t}+k_{6} D+u_{i t}$

(3) TKSAA $_{\text {it }}=1_{0}+1_{1}$ PINVSA $_{\text {it }}+1_{2}$ UTKAR $_{\text {it }}+1_{3}$ PLSA $_{\text {it }}+1_{4}$ POP $_{\text {it }}+1_{5}$ LTKSA $_{\text {it }}+1_{6}$ Dit $_{\text {it }}+u_{\text {it }}$

(4) TKSIND $_{i t}=m_{0}+m_{1}$ INVSNA $_{i t}+m_{2}$ RUTKR $_{i t}+m_{3}$ PLSIND $_{i t}+m_{4}$ POP $_{i t}+M_{5}$ LTKSIND $_{i t}+m_{6} D_{i t}+u_{i t}$

(5) TKSLL $_{i t}=n_{0}+n_{1}$ INVSNA $_{i t}+n_{2}$ RUTKR $_{i t}+n_{3}$ PLSLL $_{i t}+n_{4}$ POP $_{i t}+n_{5}$ LTKSLL $_{i t}+n_{6} D_{i t}+u_{i t}$

(6) NPTS $_{\text {it }}=q_{0}+q_{1}$ PLTSNAK $_{i t}+q_{2}$ LATS $_{i t}+q_{3}$ TKSA $_{i t}+q_{4}$ LNPTS $_{i t}+q_{5} D_{i t}+u_{i t}$

(7) NPNAK $_{i t}=r_{0}+r_{1}$ INVSA $_{i t}+r_{2}$ PLTSNAK $_{i t}+r_{3}$ TKSA $_{i t}+r_{4} J_{T B}{ }_{i t}+r_{5} J_{T U} U_{i t}+r_{6}$ LNPNAK $_{i t}+r_{7} D_{i t}+u_{i t}$

(8) $\quad \mathrm{NPTP}_{\mathrm{it}}=\mathrm{s}_{0}+\mathrm{s}_{1}$ PLTPHUT $_{\mathrm{it}}+\mathrm{s}_{2}$ LATP $_{\mathrm{it}}+\mathrm{s}_{3} \mathrm{TKSA}_{\mathrm{it}}+\mathrm{s}_{4} \mathrm{LNPTP}_{\mathrm{it}}+\mathrm{s}_{5} \mathrm{D}_{\mathrm{it}}+\mathrm{u}_{\mathrm{it}}$

(9) NPHUT $_{i t}=t_{0}+t_{1}$ PLTPHUT $_{i t}+t_{2}$ LAHUT $_{\text {it }}+t_{3}$ LNPHUT $_{i t}+t_{4} D_{i t}+u_{i t}$

(10) NPKAN $_{\mathrm{it}}=\mathrm{v}_{0}+\mathrm{v}_{1}$ INVSA $_{\mathrm{it}}+\mathrm{v}_{2}$ PLKAN $_{\mathrm{it}}+\mathrm{v}_{3}$ TKSA $_{\mathrm{it}}+\mathrm{v}_{4} \mathrm{~T}_{\mathrm{it}}+\mathrm{v}_{5} \mathrm{LNPKAN}_{\mathrm{it}}+\mathrm{v}_{6} \mathrm{D}_{\mathrm{it}}+\mathrm{u}_{\mathrm{it}}$

(11) GRDPIND $_{i t}=w_{0}+w_{1}$ INVSNA $_{i t}+w_{2}$ TKSIND $_{i t}+w_{3}$ PLSIND $_{i t}+w_{4}$ LGRDPIND $_{i t}+w_{5} D_{i t}+u_{i t}$

(12) GRDPLL $_{i t}=x_{0}+x_{1} I N V S N A_{i t}+x_{2} T_{K S L L}+x_{3} P_{\text {PSLL }}+x_{4}$ LGRDPLL $_{i t}+x_{5} D_{i t}+u_{i t}$

(13) PPMD $_{\text {it }}=y_{0}+y_{1}$ GRDPA $_{\text {it }}+y_{2}$ TKSA $_{\text {it }}+y_{3}$ PJGUR $_{\text {it }}+y_{4} L_{J P M D}+y_{5} D_{i t}+u_{i t}$

(14) PPMK $_{\mathrm{it}}=\mathrm{z}_{0}+\mathrm{z}_{1}$ GRDPIND $_{\mathrm{it}}+\mathrm{z}_{2} \mathrm{GRDPLL}_{\mathrm{it}}+\mathrm{z}_{3}$ POP $_{\mathrm{it}}+\mathrm{z}_{4} \mathrm{PJGUR}_{\mathrm{it}}+\mathrm{z}_{5} \mathrm{LJPMK}_{\mathrm{it}}+\mathrm{z}_{6} \mathrm{D}_{\mathrm{it}}+\mathrm{u}_{\mathrm{it}}$

(15) PTMK $_{\mathrm{it}}=\mathrm{aa}_{0}+\mathrm{aa}_{1} \mathrm{GRDPA}_{\mathrm{it}}+\mathrm{aa}_{2} \mathrm{GRDPIND}_{\mathrm{it}}+\mathrm{aa}_{3} \mathrm{GRDPLL}_{\mathrm{it}}+\mathrm{aa}_{4} \mathrm{POP}_{\mathrm{it}}+\mathrm{aa}_{5} \mathrm{PJGUR}_{\mathrm{it}}+\mathrm{aa}_{6} \mathrm{LPTMK}_{\mathrm{it}}+\mathrm{aa}_{7} \mathrm{D}_{\mathrm{it}}$ $+u_{i t}$

Identity equations:

(1) $\mathrm{TINV}_{\text {it }}=\mathrm{INVSA}_{\mathrm{it}}+\mathrm{INVSNA}_{\mathrm{it}}$

(2) $\mathrm{TTK}_{\mathrm{it}}=\mathrm{TKSA}_{\mathrm{it}}+\mathrm{TKSIND}_{\mathrm{it}}+\mathrm{TKSLL}_{\mathrm{it}}$

(3) $\mathrm{JGUR}_{\mathrm{it}}=\mathrm{STK}_{\mathrm{it}}-\mathrm{TTK}_{\mathrm{it}}$

(4) TGRDP $_{\text {it }}=$ GRDPA $_{\text {it }}+$ GRDPIND $_{\text {it }}+$ GRDPLL $_{\text {it }}$

(5) $\mathrm{GRDPA}_{\mathrm{it}}=\mathrm{NPTS}_{\mathrm{it}}+\mathrm{NPNAK}_{\mathrm{it}}+\mathrm{NPTP}_{\mathrm{it}}+\mathrm{NPHUT}_{\mathrm{it}}+\mathrm{NPKAN}_{\mathrm{it}}$ 
where:

INVSA = private investment in the agricultural sector $(\mathrm{Rp}$ billion $)$, PLSA $=$ direct expenditure on the agricultural sector ( $\mathrm{Rp}$ billion), $\mathrm{PPL}=$ percentage of direct expenditure to total expenditure (percent), TSBR = real interest rate (percent), $\mathrm{LW}=$ size of the area $\left(\right.$ thousand $\left.\mathrm{km}^{2}\right), \mathrm{POP}=$ total population $($ million people), LINVSA = private investment in the agricultural sector year $\mathrm{t}-1$ ( Rp billion), INVSNA = private investment in the non-agricultural sector (Rp billion), PLSLL = direct expenditure on other sectors (Rp billion), LINVSNA private investment in the non-agricultural sector year $\mathrm{t}-1$ (Rp billion), TINV $=$ total private investment $(\mathrm{Rp}$ billion), TKSA = employment in the agricultural sector (thousand people), TKSIND = employment in the industrial sector (thousand people), TKSLL = employment in other sectors (thousand people), PINVSA = percentage of private investment in the agricultural sector to total investment (percent), UTKAR $=$ labor wages in the agricultural sector ( $\mathrm{Rp}$ thousand/month), RUTKR = average wages of labor ( $\mathrm{Rp}$ thousand/month), LTKSA = employment in the agricultural sector year t-1 (thousand people), PLSIND = direct spending on the industial sector (Rp billion), LTKSIND = employment in the non-agricultural sector year $\mathrm{t}-1$ (thousand people), LTKSLL = employment other sectors in year t-1 (thousand people), TTK $=$ total employment (thousand inhabitants), JGUR = number of unemployed people (thousand people), STK = labor supply (thousand people), NPTS $=$ production value of sub-sector of the seasonal crops (Rp billion), PLTSNAK = direct expenditure on the sub-sectors of crops and livestock (Rp billion), LATS = size of seasonal crops (thousand hectares), LNPTS $=$ production value of sub-sector of the seasonal crops in year $\mathrm{t}-1$ (Rp billion), NPNAK = production value of sub-sector of the livestock (Rp billion), JTB = number of large livestock (thousand heads), JTU = number of poultry (thousand birds), LNPNAK = production value of sub-sector of the livestock year $\mathrm{t}-1$ ( $\mathrm{Rp}$ billion), NPTP $=$ production value of sub-sector of the estate $(\mathrm{Rp}$ billion $)$, PLTPHUT $=$ direct expenditure on the subsector of the estate and forestry (Rp billion), LATP $=$ real estate area (thousand hectares), LNPTP $=$ production value of sub-sector of the estate year t-1 (Rp billion), NPHUT = production value of the forestry sub-sector of (Rp billion), LAHUT = size of forest area (thousand hectares), LNPHUT = production value of the forestry subsector year $\mathrm{t}-1$ (Rp billion), NPKAN = production value of the fishery sub-sector (Rp billion). PLKAN = direct expenditures on the fishery sub-sector (Rp billion), LNPKAN = production value of the fishery sub-sector year $\mathrm{t}-1$ (Rp billion), $\mathrm{T}=$ technology (time trend), GRDPIND = GRDP of the industrial sector (Rp billion), LGRDPIND = GRDP of the industrial sector year $\mathrm{t}-1$ (Rp billion), GRDPLL = GRDP of other sectors $(\mathrm{Rp}$ billion), LGRDPLL = GRDP of other sectors year $\mathrm{t}-1$ (Rp billion), GRDPA $=$ the GRDP of the agriculture sector $(\mathrm{Rp}$ billion), TGRDP = total gross regional domestic product $(\mathrm{Rp}$ billion), PPMD = percentage of rural poor population (people), PPMK = percentage of urban poor population (people), PTPM = percentage of total poor population (people), PJGUR = percentage of unemployed people to the total labor force (percent), LPPMD = percentage of rural poor population $\mathrm{t}-1$ (people), LPPMK = percentage of urban poor population t-1 (people), LPTPM = percentage of the total poor population $\mathrm{t}-1$ (people), $\mathrm{D}=$ dummy variable for the region whose GRDP in the agricultural sector is high and low, $\mathrm{u}=$ error component.

Simulations of an increase in regional government spending on agricultural sector by 100 percent is based on the fact that the countries that successfully undergo a transformation, that is, when agriculture still contributed greatly to their GDP, public spending on the agricultural sector of these countries was about 10 percent of total public spending in 1980 (World Bank, 2008). Meanwhile, an increase in regional government spending on agriculture by 100 percent is based on that GRDP ofthe industrial sector in the agricultural sector is relatively high, but regional government spending on the industrial sector is an average of less than one percent, both in the areas where the contribution of the agricultural sector to GRDP is high and low.

\section{Results And Discussion}

\section{Regional Government Expenditures}

The average proportion of direct spending in the areas where the contribution of the agricultural sector to GRDP is low is not significantly different from GRDP areas of the high agricultural sector. The average proportion of government spending on agriculture in the areas where the contribution of the agricultural sector to GRDP is high is higher than in the areas where the contribution of the agricultural sector to GRDP is low. However, in all the regions, the average proportion of government spending on the agricultural sector is relatively small (about 4-5 percent), both the proportion of total government expenditure and the direct expenditure. The average proportion of government spending on the industrial sector, in the areas where the contribution of the agricultural sector to GRDP is low is relatively small, not significantly different from the areas where the contribution of the agricultural sector to GRDP is low. This implies that there is no area that has 
a priority of development program in agricultural or industrial development, and it is basically the allocation equity of expenditures for all sectors.

\section{Private investment}

Investment in agricultural sector in the areas where the contribution of the agricultural sector to GRDP is high is higher than in the areas where the contributionof the agricultural sector to GRDP is low. Therefore, the areas where the contribution of the agricultural sector to GRDP is high should concentrate more on the agricultural sector development program, by increasing government spending on the agricultural sector and providing various facilities (incentives) as well as the facilities to attract investors.

\section{Employment and Unemployment}

On the average, job supply, labor absorption and unemployment in the areas where the contribution of the agricultural sector to GRDP is low is higher than the areas where the contribution of the agricultural sector to GRDP is high. This is a result of a quick transfer in the economic structure from agriculture to industry and services in areas with a large population in Indonesia.

Like urban areas, theareas where the contribution of the agricultural sector to GRDP is low has been undergoing the growth of industrial and service sectors, so the structure of employment supply has shifted from agriculture to industry and other services. The average proportion of employment absorption in the areas where the contribution of the agricultural sector to GRDP is low is lower than in the areas where the contribution of the agricultural sector to GRDP is high, and this is also true with the average proportion of labor absorption in the industrial sector and other sectors.

\section{Output or Regional Gross Domestic Product (GRDP)}

On the average, the areas where the contribution of the agricultural sector to GRDP is low is over three times higher than GRDP with high agricultural sector. Almost in all regions, GRDPof the agricultural sector is more contributed by annual crops. Based on the data, each region should really know and understand its potentials, so that the regional government can develop the potentials to increase GRDP to improve the incomes of the population. In this case, the regional government may allocate its spending budget to develop the potentials of the area.

\section{Poverty}

The number and proportion of poor people in the areas where the contribution of the agricultural sector to GRDP is low is three times higher compared toin the areas where the contribution of the agricultural sector to GRDP is high. This is due to the population number in the areas where the contribution of the agricultural sector to GRDP is low. It also shows that the development of the industrial sector has not been able to significantly reduce poverty. In the areas where the contribution of the agricultural sector to GRDP is high, the number of people who live in urban areas is more than the areas where the contribution of the agricultural sector to GRDP is high, so the distribution of the urban poor population is larger. In contrast, the average distribution of the poor people in the larger rural area is higher in the areas where the contribution of the agricultural sector to GRDP is high.

\section{The impact of increased government spending on the agricultural sector, which deducts spending on other sectors}

The increased government spending on agriculture by 100 percent deducting expenditure on other sectors has an impact on increasing investment and employment in the agricultural sector, which in turn increases the output of the agricultural sector. The increased employment and output in the agricultural sector will result in the percentage of the poor in the rural areas to decline (Table 1).

On the other hand, the reduced government spending on other sectors has brought about the decrease in non-agricultural investment and employment of the industrial sector and other sectors, followed by the decrease in the output, making the percentage of the poor people in urban areas increase. Since the decline in the nonagricultural sector investment is smaller than the increase in the agricultural investment, the total investment still increases. Likewise, since the decline of employment in the industrial sector and other sectors is smaller than the increase of employment in the agricultural sector, the total employment increases and the unemployment decrease.

Due to the decrease in non-agricultural investment and employment, the GRDP of the industrial sector and other sectors decline, but it is smaller than the increase in GRDP of the agricultural sector so that the total Gross Regional Domestic Product increases. Although the percentage of the poor people in urban areas increases as a result of a decrease in employment, and in the GRDP of the industrial sector and other sectors, the 
increase is smaller than the decrease in the percentage of the poor people in rural areas so that the percentage of the total poor population decreases.

Table 1 Impact of Increased Public Spending on the agricultural sector by 100 percent, deducting the spending of other Sectors 2003-2011

\begin{tabular}{|c|c|c|c|c|c|c|}
\hline \multirow{2}{*}{\multicolumn{2}{|c|}{ EndogenVariable }} & \multirow[b]{2}{*}{ Unit } & \multicolumn{2}{|c|}{ Base Value } & \multicolumn{2}{|c|}{ Change $(\%)$} \\
\hline & & & Agriculture & $\begin{array}{c}\text { Non } \\
\text { Agriculture }\end{array}$ & Agriculture & $\begin{array}{c}\text { Non } \\
\text { Agriculture } \\
\end{array}$ \\
\hline \multicolumn{7}{|c|}{ Investment Block } \\
\hline 1. & Investment in agricultural sector & (Rp billion) & 267.20 & 251.20 & 58.76 & 77.23 \\
\hline 2. & Investment in non-agricultural sector & (Rp billion) & 321.10 & 2475.40 & -23.95 & -8.47 \\
\hline 3. & Total investment & (Rp billion) & 588.20 & 2726.50 & 13.63 & -0.58 \\
\hline \multicolumn{7}{|c|}{ Job Oppurtunity Block } \\
\hline 4. & Employment in agricultural sector & $\begin{array}{l}\text { (thousand } \\
\text { people) }\end{array}$ & 1183.30 & 2418.09 & 27.00 & 16.37 \\
\hline 5. & Employment in industrial sector & $\begin{array}{l}\text { (thousand } \\
\text { people) }\end{array}$ & 164.00 & 914.60 & -0.24 & -0.09 \\
\hline 6. & Employment in other sectors & $\begin{array}{l}\text { (thousand } \\
\text { people) }\end{array}$ & 943.00 & 3007.00 & -0.48 & -0.41 \\
\hline 7. & Total employment & $\begin{array}{l}\text { (thousand } \\
\text { people) }\end{array}$ & 2290.20 & 6340.60 & 13.74 & 6.02 \\
\hline 8. & Number of unemployment & $\begin{array}{l}\text { (thousand } \\
\text { people) }\end{array}$ & 209.00 & 609.30 & -88.06 & -42.68 \\
\hline \multicolumn{7}{|c|}{ Output Block } \\
\hline & Total GRDP & (Rp billion) & 33981.40 & 107883.00 & 13.43 & 2.37 \\
\hline 10. & GRDP in agriculture & (Rp billion) & 9435.60 & 16487.20 & 70.58 & 50.47 \\
\hline & Production value in seasonal crops & (Rp billion) & 3709.10 & 8921.70 & 106.49 & 57.11 \\
\hline & Production value in livestock subsector & (Rp billion) & 831.60 & 2226.10 & 30.44 & 14.33 \\
\hline & Production value in plantation subsector & (Rp billion) & 3172.10 & 2495.60 & 6.09 & 7.98 \\
\hline & Production value in forestry subsector & (Rp billion) & 476.40 & 950.90 & 110.62 & 59.41 \\
\hline & Production value in fishery subsector & (Rp billion) & 1246.50 & 1892.80 & 60.12 & 48.05 \\
\hline & GRDP in industrial sector & (Rp billion) & 5031.40 & 33067.90 & -8.74 & -3.62 \\
\hline & GRDP in other sectors & (Rp billion) & 19514.40 & 58327.60 & -8.49 & -7.82 \\
\hline \multicolumn{7}{|c|}{ Poverty Block } \\
\hline & Percentage of rural poor population & (percent) & 15.35 & 22.90 & -30.98 & -36.13 \\
\hline & Percentage of urban poor population & (percent) & 13.29 & 12.07 & 2.39 & 5.05 \\
\hline & Percentage of total poor population & (percent) & 14.98 & 17.79 & -25.78 & -28.57 \\
\hline
\end{tabular}

This phenomenon occurs in theare as where the contribution of the agricultural sector to GRDP is high, which is slightly different from what happens in the areas where the contribution of the agricultural sector to GRDP is low. The increased government spending on the agricultural sector, which subtractes the spending on other sectors leads to the increased investment in the agricultural sector but greatly decreased investment in nonagricultural sectors, so that the total coming-in investment in the area declines. The decrease in the total private investment does not lower the total GRDP. Furthermore, the impact of this scenario on the total decline in poverty is even higher than in the GRDP areas of the high agricultural sector. Probably, this is due to the percentage of the rural poor people in the areas where the contribution of the agricultural sector to GRDP is low is greater than in the areas where the contribution of the agricultural sector to GRDP is high.

Generally, it can be said that the increase in government spending for agriculture by 100 per cent deducted from expenditure on other sectors has an impact on effectively increasing investment, decreasing unemployment and increasing GRDP, and decreasing the percentage of the poor people in the GRDP areas of the high agricultural sector. However, in the GRDP areas of the low agricultural sector, it is only effective to decrease the percentage of the poor people.

\section{The impact of an increase in government spending on the industrial sector, which reduces spending on other} sectors

In the areas where the contribution of the agricultural sector to GRDP is high, an increase in government spending on the industrial sector by 100 percent which deducts the expenditure on other sectors has an impact on the increase in non-agricultural investment, total investment and employment in the industrial sector, which in turn increases the output of the industrial sector. The increased employment and output in the industrial sector resulted in the decrease in the percentage of the poor people in urban areas (Table 2). Meanwhile, although the regional government expenditure on other sectors declines, it does not lead to the decrease in non-agricultural investment. Probably, it is because the regional government spending on the industrial sector is relatively small, making it insignificant in decreasing non-farm investments. 
The increase in non-agricultural investments has led to the increase in employment opportunities and industrial sector output. On the other hand, the decreased government spending on other sectors has caused the decrease in job opportunities in other sectors. However, due to the increase in non-agricultural investments, the output of other sectors also increases, making the total output or GRDP increase as well. Since the employment in the industrial sector is relatively small compared to the employment in other sectors, the relatively large increase in employment in the industrial sector is not sufficient to compensate the decline in employment in other sectors so that the number of unemployed people increases .

For the agricultural sector, the increased government spending on the industrial sector by 100 percent causes the slight increase in the expenditure on the agricultural sector, which in turn increases investment, employment and output of the agricultural sector to be relatively small. The impact of the GRDP increase in agriculture, industry and other sectors is the decrease in the percentage of poverty in the rural and urban areas, and the total percentage of the poor population.

Table 2 Impact of Increased Government Spending on the Manufacturing Sector by 100 per cent, deducting the spending of other Sectors 2003-2011

\begin{tabular}{|c|c|c|c|c|c|}
\hline \multirow[b]{2}{*}{ Endogen Variable } & \multirow[b]{2}{*}{ Unit } & \multicolumn{2}{|c|}{ Base Value } & \multicolumn{2}{|c|}{ Change $(\%)$} \\
\hline & & Agriculture & $\begin{array}{c}\text { Non } \\
\text { Agriculture }\end{array}$ & Agriculture & $\begin{array}{c}\text { Non } \\
\text { Agriculture }\end{array}$ \\
\hline \multicolumn{6}{|c|}{ Investment Block } \\
\hline 1. Investment in agricultural sector & (Rp billion) & 267.20 & 251.20 & 0.79 & 0.44 \\
\hline 2. Investment in non-agricultural sector & (Rp billion) & 321.10 & 2475.40 & 19.90 & -1.59 \\
\hline 3. Total investment & (Rp billion) & 588.20 & 2726.50 & 11.24 & -1.40 \\
\hline \multicolumn{6}{|c|}{ Job Opportunity Block } \\
\hline 4. Employment in agricultural sector & $\begin{array}{l}\text { (thousand } \\
\text { people) }\end{array}$ & 1183.30 & 2418.09 & 0.35 & 0.13 \\
\hline 5. Employment in industrial sector & $\begin{array}{l}\text { (thousand } \\
\text { people) }\end{array}$ & 164.00 & 914.60 & 5.24 & -5.31 \\
\hline 6. Employment in other sectors & $\begin{array}{l}\text { (thousand } \\
\text { people) }\end{array}$ & 943.00 & 3007.00 & -0.74 & -0.08 \\
\hline 7. Total employment & $\begin{array}{l}\text { (thousand } \\
\text { people) }\end{array}$ & 2290.20 & 6340.60 & -0.40 & -0.77 \\
\hline 8. Number of unemployment & $\begin{array}{l}\text { (thousand } \\
\text { people) }\end{array}$ & 209.00 & 609.30 & 8.09 & 7.98 \\
\hline \multicolumn{6}{|c|}{ Output Block } \\
\hline 9. Total GRDP & (Rp billion) & 33981.40 & 107883.00 & 9.19 & 1.36 \\
\hline 10. GRDP in agriculture & (Rp billion) & 9435.60 & 16487.20 & 0.47 & 0.07 \\
\hline 11. Production value in seasonal crops & (Rp billion) & 3709.10 & 8921.70 & 1.63 & 0.39 \\
\hline 12. Production value in livestock subsector & (Rp billion) & 831.60 & 2226.10 & 0.43 & 0.09 \\
\hline 13. Production value in plantation subsector & (Rp billion) & 3172.10 & 2495.60 & -1.20 & -1.58 \\
\hline 14. Production value in forestry subsector & (Rp billion) & 476.40 & 950.90 & 1.93 & 0.49 \\
\hline 15. Production value in fishery subsector & (Rp billion) & 1246.50 & 1892.80 & 0.75 & 0.51 \\
\hline 16. GRDP in industrial sector & (Rp billion) & 5031.40 & 33067.90 & 33.30 & 6.99 \\
\hline 17. GRDP in other sectors & (Rp billion) & 19514.40 & 58327.60 & 7.19 & -1.47 \\
\hline \multicolumn{6}{|c|}{ Ppoverty Block } \\
\hline 18. Percentage of rural poor population & (percent) & 15.35 & 22.90 & -0.01 & -0.11 \\
\hline 21. Percentage of urban poor population & (percent) & 13.29 & 12.07 & -3.06 & -3.99 \\
\hline 22. Percentage of total poor population & (percent) & 14.98 & 17.79 & -1.93 & -2.64 \\
\hline
\end{tabular}

In the areas where the contribution of the agricultural sector to GRDP is high, the increased government spending on the industrial sector which subtracts the spending on other sectors has caused nonagricultural sector investment and total investment to decline. As a result, the job oppurtunities in the industrial sector and other sectors decline, increasing the number of jobless people. The decrease in job oppurtunities in the industrial sector has no impact on GRDP decline in the industrial sector. The GRDP in the industrial sector increases due to an increase in non- agricultural investments. On the other hand, because government spending on other sectors declines, the GRDP of other sectors also declines. However, the decreased GRDP in other sectors is smaller than the increased GRDP in the industrial sector, increasing the total GRDP. The decrease in the percentage of the poor people in rural and urban areas, and the total poor population is greater than in the areas where the contribution of the agricultural sector to GRDP is high. Probably, it is due to the percentage of the poor people in the urban areas, where the contribution of the agricultural sector to GRDP is low, is greater than in the areas where the contribution of the agricultural sector to GRDP is high.

\section{Conclusion}

a. Allocation of regional government spending in Indonesia is not stressed on the development of certain economic sectors. 
b. Although the total investment decreased and the percentage of the urban poor increased spending, the increase in the agricultural sector which is subtracted from the spending of other sectors, can effectively reduce the number of unemployed people, and the percentage of the total poor population, as well as increase the total output in the GRDP of the low agricultural sector. In areas of high agricultural sector, the increase in government spending on the agricultural sector effectively increases private investment, employment, total GRDP and reduces the total poor population.

c. The increase in government spending on the industrial sector is deducted by spending on the other sectors, both the areas where the contribution of the agricultural sector to GRDP is high and the areas where the contribution of the agricultural sector to GRDP is low, only increasing the GRDP of the industrial sector, but the success indicators of other economic developments show the direction of setbacks.

\section{References}

[1]. Ahmed, H. dan S.M. Miller. 2000. Crowding-out and Crowding-in Effects of The Components of Government Expenditure. Contemporary Economic Policy, 18, 1; 124-133

[2]. Barro, R.J. 1990. Government Spending in a Simple Model of Endogenous Growth. Journal of Political Economy, 98; 103-125

[3]. Branson, W.H. 1979. Macroeconomic. Theory and Policy. Harper and Raw. Michigan.

[4]. Departemen Dalam Negeri. 2004. Undang-undang Nomor 33 Tentang Perimbangan Keuangan Antar Pemerintah Pusat dan Daerah. Penerbit Sinar Grafika. Jakarta.

[5]. Fugli, K.O. 2004. Productivity Growth in Indonesia Agriculture, 1961-2000. Bulletin of Indonesian Economic Studies, 40, 2; 209225

[6]. Jhingan, M.L. 2008. Ekonomi Pembangunan dan Perencanaan. Raja Grafindo Persada. Jakarta.

[7]. Liu, L.C; C.E. Hsu and M.Z. Younis. 2008. The Association Between Government Expenditure and Economic Growth: Granger Causality Test of US Data, 1947-2002. Journal of Public Budgeting Accounting \& Financial Management, 20, (4); 537-553

[8]. Lopez, R. and G.I. Galinato. 2007. Should Governments Stop Subsidies to Private Goods? Evidence from Rural Latin America. Journal of Public Economics, 91; 1071-1094

[9]. Mellor, JW. 1995. Agriculture on the Road to Industrialization. The John Hopkins University Press. Baltimore and London.

[10]. Musgrave, R.A. and B.M. Peggy. 1989. Public Finance in Theory and Practice. McGraw-Hill Book Company. New York.

[11]. Priyarsono, D.S. 2011. Dari Pertanian ke Indunstri, Analisis Pembangunan dalam Perspektif Ekonomi Regional. IPB Press. Bogor.

[12]. Rostow, WW. 1960. The Stages of Economic Growth. A Non-Communist Manifesto. Cambridge at the University Press. New York.

[13]. Stiglitz. J.E. 2000. Economics of the Public Sector. W.W. Norton and Company. New York.

[14]. Todaro, M.P. 2000. Economic Development. Seventh Edition. Addision Wesley Longman. Inc. New York.

[15]. Wang, B. 2005. Effects of Government Expendinture on Private Investment: Canadian Empirical Evidence. Empirical Economics. 30; 493-504

[16]. World Bank. 2008. Laporan Pembangunan Dunia 2008 - Agriculture untuk Pembangunan. Salemba Empat, The World Bank. Jakarta.

[17]. World Bank. 2009. Indonesia Agriculture Public Expenditure Review - Indonesia Agriculture Public and Growth. Policy Notes. The World Bank Office Jakarta. 